\title{
当院における大腿骨転子間骨折の治療経験
}

\author{
ヨコクラ病院整形外科 \\ 柴 田 陽 三・横 倉 義 武 \\ 福岡大学病院整形外科 \\ 黒田康二・浅川康司 \\ 福岡大学筑紫病院整形外科 \\ 木 梨 博 史 \\ 大分整形外科病院 \\ 花 村 達 夫
}

\section{Intertrochanteric Fractures: A Comparison Between Fixation with a Compression Hip Screw and Ender's Nails.}

by

\author{
Yozo Shibata and Yoshitake Yokokura \\ Yokokura Hospital, Miike-gun \\ Koji Kuroda and Yasusi Asakawa \\ Department of Orthopedic Surgery, \\ Fukuoka University \\ Hirofumi Kinashi \\ Department of Orthopedic Surgery, \\ Chikushi Hospital \\ Tatsuo Hanamura \\ Oita Orthopedic Hospital
}

Fifty cases of intertrochanteric fracture were treated operatively. Nineteen cases were treated using Ender's intramedullary nails and 31 cases using compression hip screws. Those fractures fixed with Ender's nails tended to develop varus deformity, pain at the insertion area of the nails and distal migration of the nails at the knee. Each fracture was classified according to classification of Evans. Good results were obtained in $64 \%$ of stable type and $73.3 \%$ of unstable type using compression hip screws, and in $33.3 \%$ of stable type and $20 \%$ of unstable type useing Ender's nails.

\section{はじめに}

大腿骨転子間骨折は全身的な合併症を有する高令者 に発生してくるために骨折部を手術的に固定して除痛 をはかり早期離床をさせることが推奨されている。わ れわれは大腿骨転子間骨折に対して主にエンダー法と コンプレッションヒップスクリュウ法 (以下CHS) を 用いてきた。これらの術後成績を Evans の分類 ${ }^{1}$ によ

\section{り検討を加えた。}

\section{対象および方法}

昭和 60 年 1 月より昭和 62 年 12 月までの間にエンダ 一法を 19 例に, CHS 法を 31 例に行った. 術後経過期 間は最短 6 力月最長 3 年 5 力月, 平均 1 年 11 力月であ った. 男は 13 例, 女 37 例と女が多く, 年令は 66 才か ら 93 才で平均 80.6 才であった(表 1 )。これらの症例 


\begin{tabular}{|c|c|c|c|c|}
\hline & & 男 & 女(名) & 平均年令 (才) \\
\hline $\begin{array}{l}\text { C H S } \\
\text { エンダー }\end{array}$ & $\begin{array}{l}\text { 安 定 型 } \\
\text { 不安定型 } \\
\text { 安 定 型 } \\
\text { 不安定型 }\end{array}$ & $\begin{array}{l}2 \\
4 \\
2 \\
5\end{array}$ & $\begin{array}{r}12 \\
13 \\
4 \\
8\end{array}$ & $\begin{array}{ll}78.1 & (66 \sim 86) \\
82.6 & (77 \sim 90) \\
82.8 & (68 \sim 93) \\
80.4 & (68 \sim 92)\end{array}$ \\
\hline 合 & 計 & 13 & 37 & 80.6 \\
\hline
\end{tabular}

表 2 手術時間と出血量

\begin{tabular}{|c|c|c|c|}
\hline & & 手術時間 (分) & 出 血 量 $(\mathrm{g})$ \\
\hline $\mathrm{CH} \mathrm{S}$ & $\begin{array}{l}\text { 安 定 型 } \\
\text { 不安定型 }\end{array}$ & $\begin{array}{ll}63.8 & (35-97) \\
70.9 & (40-100)\end{array}$ & $\begin{array}{l}164.2(50-320) \\
224.4(100-350)\end{array}$ \\
\hline エンダー & $\begin{array}{l}\text { 安 定 型 } \\
\text { 不安定型 }\end{array}$ & $\begin{array}{ll}31.8 & (17-42) \\
36 & (27-60)\end{array}$ & $\begin{array}{l}64 \\
95\end{array}\left(\begin{array}{l}45-82) \\
(50-150)\end{array}\right.$ \\
\hline
\end{tabular}

を受傷原因, 手術時間, 出血量, 荷重開始時期, 歩行 能力を術式および骨折型に分けて検討を加えた。

\section{結果}

\section{1. 受傷原因}

受傷原因は転倒がもっとも多く 43 例を占めた。その 他交通事故 5 例, 転落が 2 例であった。

2. 手術時間と出血量

手術時間は CHS 法で約 1 時間かかったのに比し,エ ンダー法では 30 分台ですみ, また両術式共不安定型で やや長い傾向にあった，手術時間に比例して出血量も 多くなっており,エンダー法の方が少なくてすんだ(表 2 ).

3. 荷重開始時期

荷重開始時期は CHS 法安定型で 7 ～27（平均 17.8 日), 不安定型で $14 \sim 45$ 日（平均 26.9 日）であった。 エンダー法安定型では 14〜30 日 (平均 20.8 日), 不安 定型 21〜 40 日（平均 30.2 日）であった。

\section{4. 入院期間}

他疾患の治療のため長期入院となったものを除けば CHS 法安定型で 30 115 日 (平均 62.2 日), 不安定型 で 45〜128日 (平均 93 日) であった。エンダー法では 安定型で $22 \sim 110$ 日 (平均 71.5 日), 不安定型で 44〜157 日（平均 108.6 日）であり, CHS 法に比して やや長い傾向にあった。

5. 歩行能力について

歩行能力を独歩，杖歩行，押し車，つかまり歩き， ベッド上寝たきりの 5 段階に分けて評価してみた。

\section{(1)成績良好例}

調査時受傷前と同じレベルの歩行をしているか, レ ベル下降しても押し車以上の歩行をしていたものを成 績良好例とした.死亡例と調查不能例を除いた 42 例に ついて検討してみると, CHS 法では安定型の 14 例中 9 例 $(64.3 \%)$, 不安低型の 15 例中 11 例 $(73.3 \%)$ ，工 ンダー法では安定型の 3 例中 1 例 (33.3\%), 不安定型 の 10 例中 2 例 $(20 \%)$ がこれに該当した。これらは 92 才のエンダー法施行例を除けば CHS 安定型が 66〜84 才 (平均 75.8 才), 不安定型が $77 \sim 82$ 才 (平均 79.7 才), エンダー法安定型が 78 才, 不安定型が 74 才と若 い傾向にあったほほとんど全例が高血圧を合併症とし て有していたが特に重篤な全身疾患を有するものはな く, 年令の低さも併せて成績良好となったものと考え た.

(2)成績不良例

とくにベッド上㾛たきりとなった症例を成績不良例 として調べてみた.CHS 法施行例では安定型 14 例中 1 例, 不安定型 15 例中 2 例が漫たきりとなっていた. 3 例とも受傷前の歩行状態はつかまり歩きで平均年令も 85.6 才と高かった. 成績不良因子としては高令, 痴呆 による意欲の低下と同側の変形性膝関節症による疼痛 が関与しているものと考えられた. エンダー法では受 傷前つかまり歩きをしていた 1 例を除き全例押し車以 上の歩行をしており, 平均年令も 76.4 才と若かった. 受傷前の歩行能力が比較的良好で年令が若いのにもか かわらず成績不良となっていたが，その原因として痴 呆，エンダー釘の膝刺入部痛が考えられた（表 3 ).

6. レントゲン的検討

エンダー法で手術手技のまずさによるピンの逸脱が 2 例, 後に骨頭穿孔を起こしてきたものが 2 例, 強い 内反股を呈したものが 5 例あり，これらのうち成績良 好例は 1 例のみであった. CHS ではこうした変化は認 められなかった２例においてラグスクリュウが骨頭 および大腿骨頝部の辺縁に入っていたが受傷前と同じ 歩行能力を呈し, 術後成績には影響がなかった。

7. 死亡例の検討

死亡退院が 5 例あり CHS 法 1 例, エンダー法 4 例で あった. 受傷前の歩行能力はつかまり歩き 2 例, 押し 車 3 例と悪かった. また平均年令も 84.6 才と高く, 4 例に痴呆が見られた。疼痛からの逃避, 認識力の低下 が後療法への意欲を低下させ寝たきりとなり,ひいて は全身状態が悪化して死亡へと至っていた。ただし術 
表 3 成 績 不良例 の 検 討

\begin{tabular}{|c|c|c|c|c|c|c|}
\hline & & & & 受傷 前歩行能力 & 原 & 因 \\
\hline $\mathrm{C}$ & $\begin{array}{l}\mathrm{H} \quad \mathrm{S} \\
\text { 安 定 } \text { 型 }(1 / 14) \\
\text { 不安定型 }(2 / 15) \\
\text { ン 平均 年令 } \\
\text { 安定 型 }(1 / 3) \\
\text { 不安定型 }(6 / 10)\end{array}$ & $\begin{array}{l}86 \text { 才 } \\
86 \text { 才 } \\
90 \text { 才 } \\
85.6 \\
68 \text { 才 } \\
68 \text { 才 } \\
78 \text { 才 } \\
80 \text { 才 } \\
76 \text { 才 } \\
87 \text { 才 } \\
76 \text { 才 } \\
76.4\end{array}$ & $\begin{array}{l}\text { 男 } \\
\text { 女 } \\
\text { 女 } \\
\text { 女 } \\
\text { 男 } \\
\text { 男 } \\
\text { 女 }\end{array}$ & 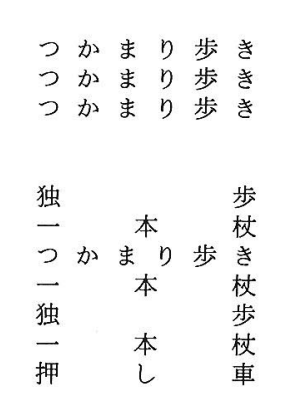 & 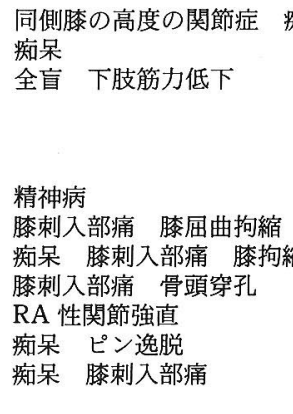 & 窽呆 \\
\hline
\end{tabular}

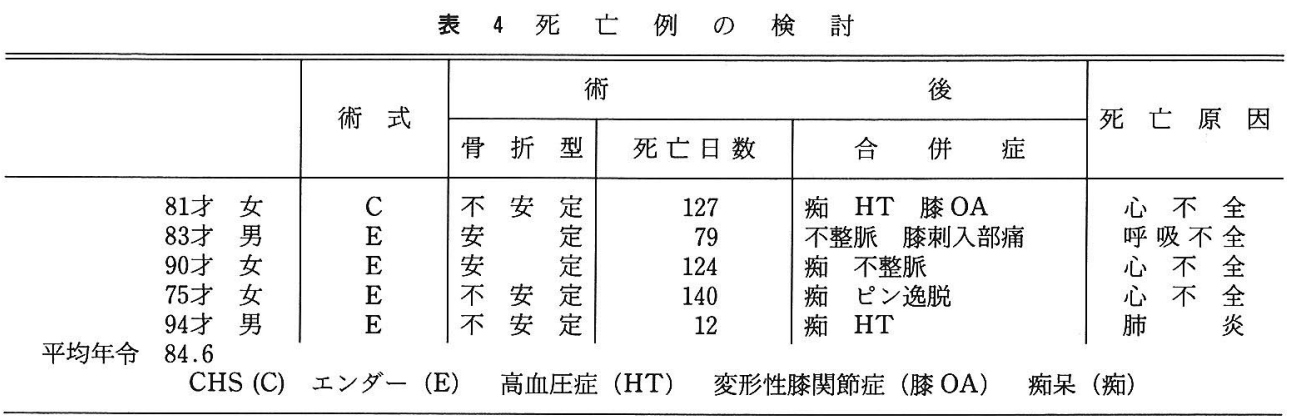

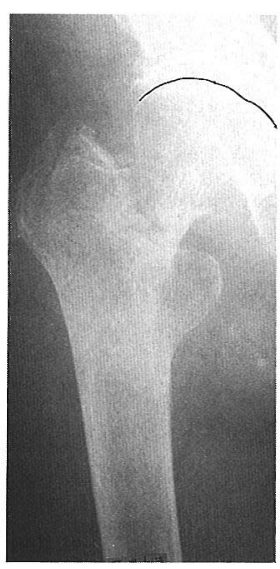

術前

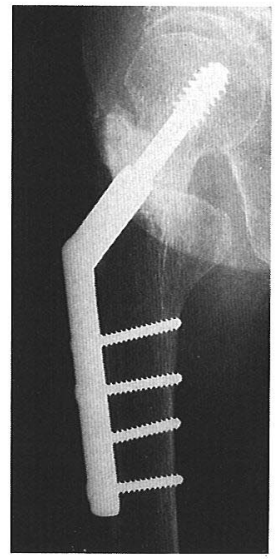

骨癒合後

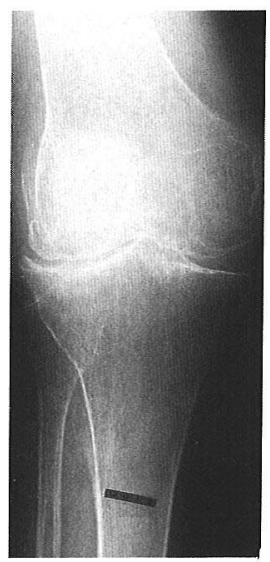

変形性膝関節症

図 1 症例 $2: 86$ 才, 女性. Type I grade 2

解剖学的に整復骨瘺合を得ているが同側膝に変形性膝関節症を見, 成績悪化因子となっている。

後 12 日で死亡した 1 例を除き他は全例 2 力月以後に死 となったとは考えられなかった（表 4).

亡しており，これらについては手術侵襲が直接の死因 8. 症例供覧 


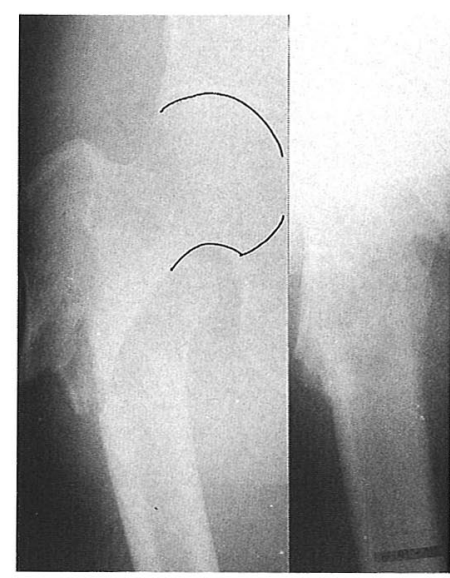

術前

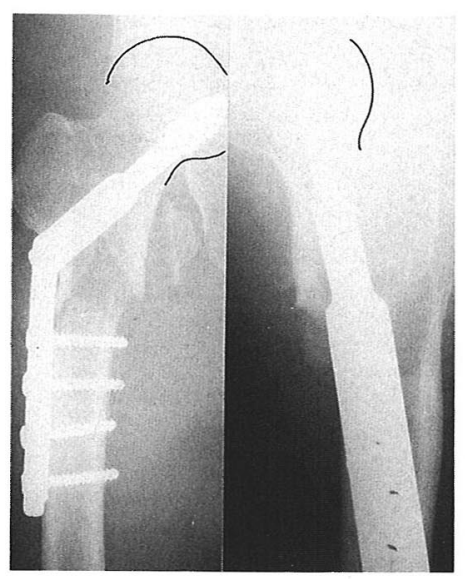

術直後

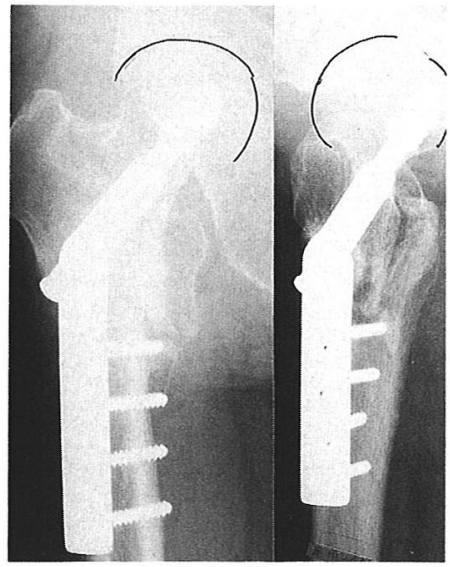

骨瘾合後 1 年 5 力月後

図 2 症例 $4: 82$ 才, 女性. Type II

末梢骨片の内側移動が生じているが骨㾍合は良好

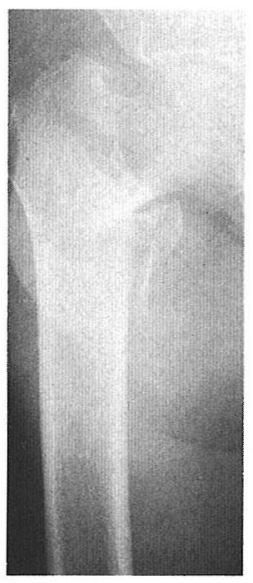

術前

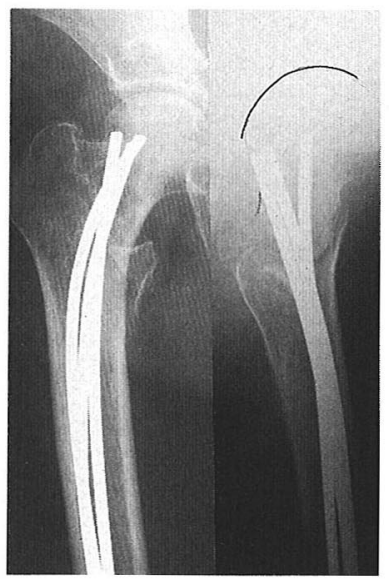

術直後

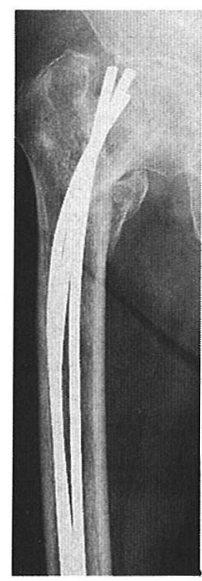

骨頭穿孔 術後 3 力月

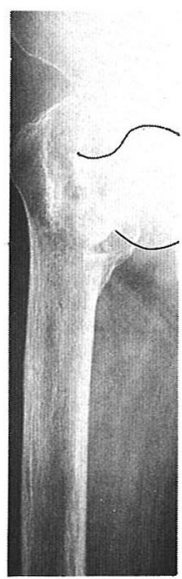

骨療合後 2 年 6 力月後

図 3 症例 $6: 78$ 才, 女性. Type I grade 2 エンダーピンの骨頭穿孔を生じ, 4 力月後に抜釘. 骨㾍合後 2 年 6 カ月内反変形を起して骨癒合を起している.

症例 2:86 才，女性。

Type I Grade 2 受傷前杖歩行。痴呆のため意欲な く, また同側の滕の関節症による疼痛のために歩行訓 練が進まず術後 1 年 6 カ月の現在つかまり歩行をして いる(図 1).

症例 $4: 82$ 才, 女性.

Type II ラグスクリュウの telescoping が起こらない タイプであったので，免荷の期間を長めにして 5 週後
より徐々に荷重を開始した。プレートの折損も起こさ ずに, 1 年 5 カ月の現在独歩歩行をしている（図2）。 症例 $6: 71$ 才, 女性。

Type I Grade 2 術直後の側面像で既に 2 本が骨頭 穿孔を起こしかけている. 3 力月で骨頭穿孔とピン下 降による膝痛を訴えてきたために 4 力月目に抜釷術施 行. 内反股となって骨癒合したが，一本杖にて歩行し ている(図3)。 


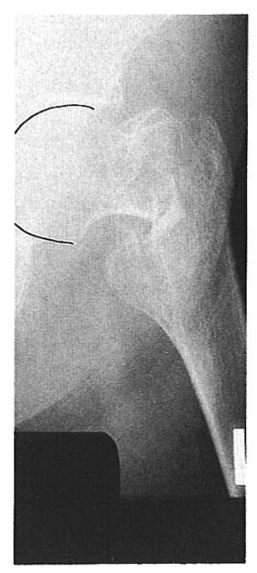

術前

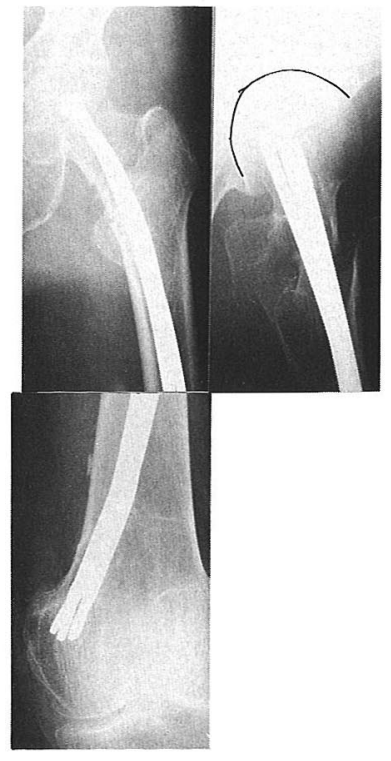

術直後

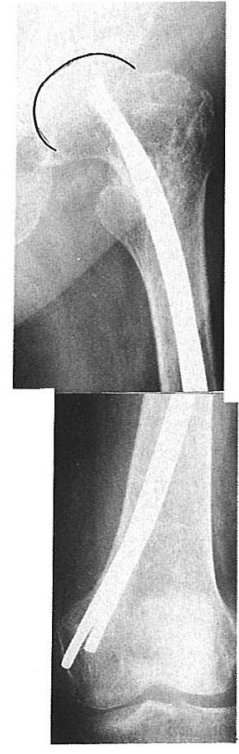

術後 4 力月半

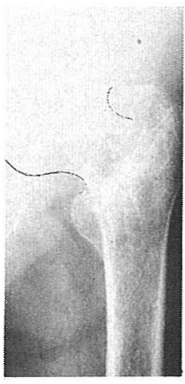

抜釘直後

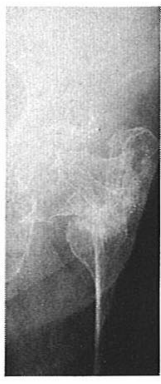

8 力月後

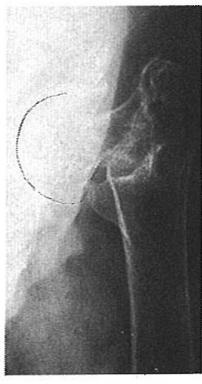

2 年 8 力月後

図 4 症例 $7: 76$ 才, 女性. Type I grade 2 ピンの下降により膝内側部痛を生じた。

骨瘾合をまって術後 4 カ月半で抜釘. 抜釘後徐々に内反変形が進行

症例 $7: 76$ 才, 女性.

Type I Grade 2 受傷前押し車歩行。痴呆高度で膝 内側刺入部痛のために 4 力月半で拢釘。骨瘾合してい たかのようであったが, 内反変形進行し 2 年 8 カ月の 現在寝たきりとなっている(図 4)。

症例 $8: 92$ 才, 女性.

Type I Grade 35 週すぎより徐々に荷重. 軽度の 痴呆のあるものの非常に活動的で膝内側の刺入部痛も なく独歩歩行をしている（図 5 )。
考察

エンダー法の手術適応については表 5 のごとく報告 があるが，1の積極的な意見を除けばそれ以外は内反 変形やそれに伴うピンの下降の問題を危惧してのもの

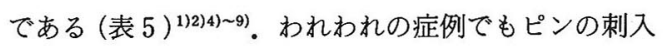
部刺激痛は大きな問題でエンダー法 18 例中 11 例（61 \%)に見られれ，成績悪化因子の一つと考えられた。 CHS 法についても，ラグスクリューの骨頭穿孔，プレ 一トとの接合部の脱転, プレート屈曲部の折損の頻度 が 2 8 \%程度見られるとの報告があるが, 幸いわれわ 


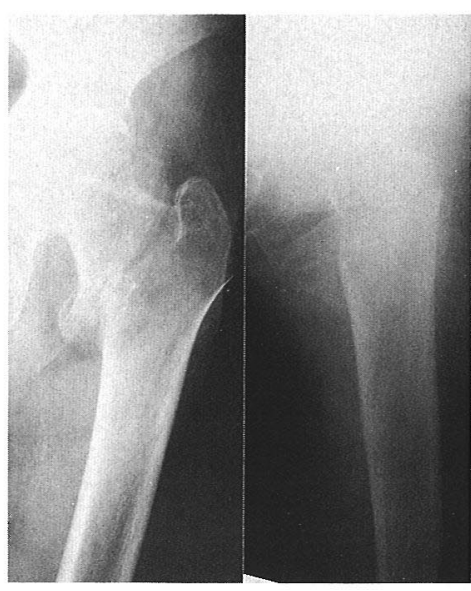

術前

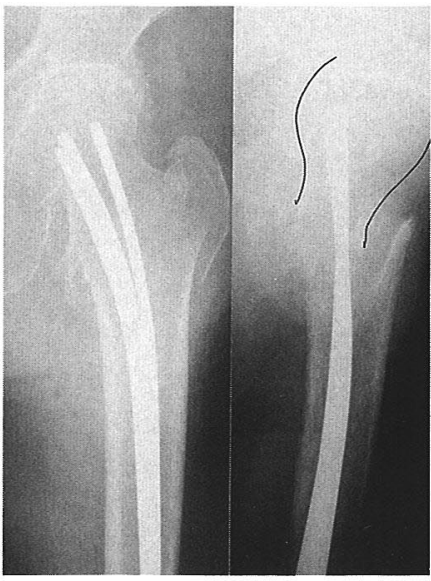

術直後

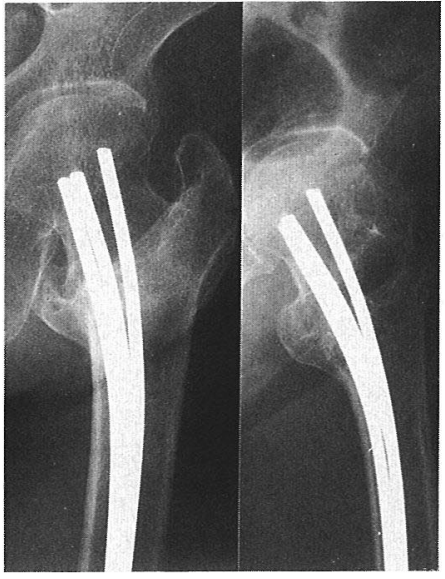

術後 3 年

図 5 症例 $8: 92$ 才, 女性. Type I grade 3

ピンの軽度下降が認められるものの, 内反変形はなく, 䐂痛も訴えない.

表 5 エンダー法の適応に関する報告

1. 転子間骨折，転子下骨折のすべてに用いることがで き, 早期の運動が可能である。

Aprin (1980), Hall (1981), Pankovich (1980)

2. 数週間の非荷重, 率引, 安静がとれるならば不安定型 にも可能である。

Chapman (1981), Russin (1980)

3. 不安定型には用いない。

Iwegbu (1981), Levy (1983)

4. 大腿骨頝部基底部骨折か転位のない安定型骨折が適 応となる。

Strathy (1984)

れの症例では生じていなかった。

エンダー法は手術侵襲が少なく高令者に適した手術 であると考えられているが，われわれの症例では残念 ながら安定した成績を得ることが出来なかった。それ に比して CHS 法では比較的良好な成績を得ることが出 来たため，最近ではエンダー法は行っていない。

\section{ま と め}

1. 術式を問わず高年令, 痴呆, 全身状態の悪化が 成績に影響を与えた。

2. CHS 法ではレントゲン所見にえる成績の違いは みられなかった。

3.エンダー法では骨頭穿孔，初期の逸脱が合わせ て 19 例中 4 例に見られた。また㯟刺入部痛を訴えたも のが 18 例 11 例㧍り成績不良因子の一つと考えられた。

4. 調查時受傷前と同じレベルか, 下降しても押し
車以上の歩行能力を呈していたものがCHS 法で安定型 が $64.3 \%$ ，不安定型で $73.3 \%$ ，エンダー法で安定型 $33.3 \%$, 不安定型 $20 \%$ と CHS 法の法が成績が安定し ていた.

$$
\text { 文献 }
$$

1) Aprin et al.: Treatment of Trochanteric Fractures with Ender Rods. J. Trauma, 20:32-42, 1980.

2) Chapman, M.W.: The Use of Ender's Pins in Extracapsular Fractures of the hip. J. Bone and Joint Surg., 63-A : 14-28, 1981.

3) Evans, E.M.: The Treatment of Trochanteric Fractures of the Femur. J. Bone and Joint Surg., 13 -B, 190- , 1949.

4) Hall: Compression of Nail Plate Fixation and Ender's Nailing for Intertrochanteric fractures. J. Bone and Joint Surg., 63-B, : 24-28, 1981.

5) Iweglw, G. G.: Difficulties and Comprications of the Ender Method of Treatment of Trochanteric Fractures of the Femur. Injury, 13: 116-124, 1981.

6) Levy, R. N.: Comprication of Ender Pin Fixation in Basicervical, Intertrochanteric and Subtrochanteric Fractures of the Hip. J. Bone and Joint Surg., 65-A : 66-69, 1983.

7) Pakovich, A. M.: Ender Nailing of intertrochanteric and Subtrochanteric Fractures of the Femur. Comprications, Failures and Errors. J. Bone and Joint Surg., 62-A : 635-645, 1980.

8) Russin, L. A. : Treatment of Intertrochanteric and Subtrochanteric Fractures with Ender's Intramedullary Rods. Clin. Ortop., 148: 203-212, 
1980.

9) Strathy, G. M.: Ender's Pinning for Fractures about the Hip. Mayo Clin., 59: 411-414, 1984.

質 問 佐賀県立好生館 奥江 章

エンダー術を 50 例位を経験しないと仲々うまくゆか ないようです．うまく治療するにはもう少し経験する 必要ありと思いますがいかがでしょうか.

\section{解 答 ヨコクラ病院 柴田 陽三}

エンダー法の手術成績が向上する上で本法を続ける

よりは, 現時点でCHS を用いる事でほほ満足できる結
果を得ているためにあえてエンダーを続けるという利 点はないように考えています。

質 問 福岡整形外科病院 徳永 純一

Type II骨折ではテレスコーピングが働かないため, CHS の適応とはならないと思うが.

解 答 ヨコクラ病院 柴田 陽三

Type II骨折は CHS の利点であるテレスコーピング 機構が働かず,たしかにCHS に対する責極的な適応に はならないと思います. 本症例も荷重時期はレントゲ ンを詳細に検討し, 慎重に決定しています。 